\title{
Effect of acarbose on milk yield and composition in early-lactation dairy cattle fed a ration to induce subacute ruminal acidosis
}

\author{
C. L. McLaughlin, ${ }^{* 1}$ A. Thompson, $†$ K. Greenwood, ${ }^{*}$ J. Sherington, $\dagger$ and C. Bruce \\ *Pfizer Animal Health, 7000 Portage Road, Kalamazoo, Ml 49001 \\ †Pfizer Animal Health, Ramsgate Road, Sandwich, Kent, CT13 9NJ, United Kingdom
}

\begin{abstract}
Subacute ruminal acidosis reduces lactation performance in dairy cattle and most often occurs in animals fed a high concentrate:forage ration with large amounts of readily fermentable starch, which results in increased production of volatile fatty acids and lactic acid and a reduction in ruminal $\mathrm{pH}$. Acarbose is commercially available (Glucobay, Bayer, Wuppertal, Germany) and indicated for the control of blood glucose in diabetic patients. In cattle, acarbose acts as an $\alpha$-amylase and glucosidase inhibitor that slows the rate of degradation of starch to glucose, thereby reducing the rate of volatile fatty acid production and maintaining rumen $\mathrm{pH}$ at higher levels. The ability of acarbose to reverse the reduced feed intake and milk fat percentage and yield associated with a high concentrate:forage ration with a high risk of inducing subacute ruminal acidosis was evaluated in 2 experiments with lactating dairy cattle. In 2 preliminary experiments, the effects of a 70:30 concentrate:forage ration on ruminal $\mathrm{pH}$ and lactation were evaluated. Ruminal $\mathrm{pH}$ was monitored in 5 Holstein steers with ruminal cannulas every 10 min for $5 \mathrm{~d}$. Ruminal $\mathrm{pH}$ was $<5.5$ for at least $4 \mathrm{~h}$ in $79 \%$ of the animal days. In dairy cows, the $70: 30$ concentrate:forage ration decreased feed intake $5 \%$, milk fat percentage $7 \%$, and milk fat yield $8 \%$ compared with a 50:50 concentrate:forage ration but did not affect milk yield. Early lactating dairy cattle were offered the 70:30 concentrate:forage ration with 0 or $0.75 \mathrm{~g} / \mathrm{d}$ of acarbose added in a crossover design in 2 experiments. In the first experiment, acarbose increased dry matter feed intake (23.1 vs. $21.6 \mathrm{~kg} / \mathrm{d}$ ) and $3.5 \%$ fat-corrected milk yield (33.7 vs. $31.7 \mathrm{~kg} / \mathrm{d}$ ) because of an increase in percentage milk fat (3.33 vs. 3.04\%) compared with control cows. In the second experiment, cows were fasted for $3 \mathrm{~h}$ before the morning feeding to induce consumption of a large meal to mimic conditions that might be associated with unplanned delayed feed-
\end{abstract}

Received October 30, 2008

Accepted May 11, 2009.

${ }^{1}$ Corresponding author: carol.mclaughlin@pfizer.com ing. In this experiment, acarbose also increased feed intake (22.5 vs. $21.8 \mathrm{~kg} / \mathrm{d}$ ) and $3.5 \%$ fat-corrected milk yield ( 36.9 vs. $33.9 \mathrm{~kg} / \mathrm{d}$ ) due to increased percentage milk fat (3.14 vs. 2.66\%) compared with controls. Thus, acarbose reversed the decreased feed intake and low milk fat percentage and yield associated with feeding a high concentrate:forage ration shown to induce subacute ruminal acidosis in Holstein steers.

Key words: subacute ruminal acidosis, acarbose, dairy cow, milk yield

\section{INTRODUCTION}

Subacute ruminal acidosis (SARA) occurs in both lactating dairy cattle and finishing beef cattle and is primarily a result of intake of large amounts of concentrate without adequate forage to stimulate chewing and saliva production to buffer the consequent low pH (Owens et al., 1998). High-producing dairy cows are at greater risk of SARA caused by feeding of high concentrate:forage rations with a high percentage of readily fermentable carbohydrates to support milk yield. Subacute ruminal acidosis is associated with decreased feed intake, milk yield, and milk fat percentage as well as diarrhea, lameness, and increased incidence of displaced abomasa (e.g., Krause and Oetzel, 2006; Plaizier et al., 2008). Incidence of SARA in herds receiving TMR based on ruminal $\mathrm{pH}<5.5$ in $25 \%$ of animals tested is from 20 to $30 \%$ (Garrett et al., 1999). Subacute ruminal acidosis has also been observed in approximately $10 \%$ of dairy animals grazing pastures with highly fermentable grass and offered concentrates (Bramley et al., 2008; O'Grady et al., 2008). Subacute ruminal acidosis was associated with lower $\mathrm{pH}$, higher milk yield, lower percentage milk fat, and higher total ruminal VFA in these studies.

Several short-term animal models of SARA have been developed to understand effects of various treatments on ruminal pH (e.g., Keunen et al., 2002; Krause and Oetzel, 2005). However, chronic models are more representative of the commercial environment; increasing amounts of dietary concentrate and starch in a variety of experiments have resulted in lower rumen $\mathrm{pH}$ and 
Table 1. Formulation of 70:30 concentrate:fiber ration for all experiments

\begin{tabular}{lc}
\hline Ingredient & \% of DM \\
\hline Ration composition & \\
Corn silage & 30.0 \\
Concentrate & 70.0 \\
Concentrate composition, ground through 3-mm screen & \\
Ground corn & 60.0 \\
Base mix & 23.0 \\
Soybean meal, 48\% & 17.0 \\
Base mix & \\
SoyPlus & 49.8 \\
Corn gluten meal, 60\% & 13.6 \\
Megalac & 15.2 \\
Calcium carbonate & 10.4 \\
Dicalcium phosphate & 4.9 \\
Salt & 3.8 \\
Magnesium oxide & 1.7 \\
Dairy vitamin/trace mineral premix 2/5 & 0.3 \\
Selenium $600,{ }^{3}$ 0.06\% & 0.3 \\
\hline
\end{tabular}

${ }^{1}$ West Central, Ralston, IA.

${ }^{2}$ Arm \& Hammer, Princeton, NJ.

${ }^{3}$ Diamond V, Cedar Rapids, IA.

acetate:propionate ratio, higher VFA concentrations and milk yield, and lower milk fat percentage (Khorasani and Kennelly, 2001; Maekawa et al., 2002; Krause et al., 2003). Various methods of controlling ruminal $\mathrm{pH}$ and SARA such as sodium bicarbonate or monensin have been tested in these models; however, neither of the latter methods has consistently maintained $\mathrm{pH}$ values greater than those associated with SARA (Mutsvangwa et al., 2002; Hu and Murphy, 2005; Paton et al., 2006). Addition of yeasts has more consistently increased ruminal pH (Bach and Andrieu, 2007; Bach et al., 2007; Thrune et al., 2009), but there are no or only small effects on lactation performance (Higginbotham et al., 1994; Swartz et al., 1994; Oetzel et al., 2007). A new approach for controlling rumen $\mathrm{pH}$ when large amounts of highly fermentable carbohydrate are fed is the use of an $\alpha$-amylase and glucosidase inhibitor to slow the rate of degradation of starch by amylase to maltose and then glucose. Consequently, rate of rumen VFA production is reduced and rumen $\mathrm{pH}$ is maintained at a higher level. A commercially available $\alpha$-amylase and glucosidase inhibitor, acarbose (Glucobay, Bayer, Wuppertal, Germany), is indicated for the control of blood glucose in human diabetic patients. Acarbose has been shown to control incidence and severity of acute acidosis in a starch challenge model (Keane et al., 2008; McLaughlin et al., 2009) and to increase $\mathrm{pH}$ and decrease VFA production in an in vitro model (Speight and Harmon, 2005; Speight et al., 2007). The ability of acarbose to reverse the decreased intake, milk fat percentage, and milk fat yield associated with SARA was evaluated in lactating dairy cows offered a ration shown to induce SARA in Holstein steers both ad libitum and after a daily fast of $3 \mathrm{~h}$ before the morning feeding to induce a large meal.

\section{MATERIALS AND METHODS}

Pfizer Institutional Animal Care and Use Committee approval was obtained before the commencement of these studies.

\section{Preliminary Experiments with a 70:30 Concentrate:Forage SARA Ration}

Preliminary Experiment 1 in Steers. Five Holstein steers with rumen fistulas were used to evaluate the ability of a 70:30 concentrate:forage ration to induce SARA. Steers initially weighing $685 \pm 24 \mathrm{~kg}$ were adapted to the ration in Table 1 (formulation) and Table 2 (nutrient composition) and were fitted with a backpack containing a WTW340 pH meter (WTW Company, Weilheim, Germany). A SenTix $41 \mathrm{pH}$ probe (WTW Company) was inserted into the rumen through the cannula and recorded ruminal $\mathrm{pH}$ every $10 \mathrm{~min}$ for $24 \mathrm{~h}$. The probe was removed for cleaning and recalibration and the $\mathrm{pH}$ data were downloaded into an Excel spreadsheet daily. Feed was offered ad libitum twice daily and orts were recorded once daily. Feed intake, number of hours that $\mathrm{pH}<5.5$, and average ruminal $\mathrm{pH}$ data were summarized for each of $5 \mathrm{~d}$ as means and standard errors of the mean. No statistical comparisons between days or animals were made, as the objective was to show how frequently the criterion for SARA was met.

Preliminary Experiment 2 in Lactating Dairy Cattle. The effects of the 70:30 concentrate:forage ration in Table 1 were compared with those of a 50:50 concentrate:forage in 28 lactating dairy cows (150-180 DIM). Cows were randomly assigned the treatment sequence of the 50:50 concentrate:forage ration followed by the 70:30 concentrate:forage ration or the opposite sequence according to a crossover design of two 10-d periods. Data for the last $7 \mathrm{~d}$ of each period were analyzed.

Table 2. Nutrient composition of the 70:30 concentrate:forage ration for preliminary experiment 1 (calculated from NRC, 2001; values for individual ingredients)

\begin{tabular}{lc}
\hline Component & $\%$, DM basis \\
\hline $\mathrm{DM}$ & 58.0 \\
$\mathrm{CP}$ & 18.9 \\
$\mathrm{ADF}$ & 12.9 \\
$\mathrm{NDF}$ & 21.6 \\
$\mathrm{NFC}^{1}$ & 52.9 \\
\hline
\end{tabular}

${ }^{1} \mathrm{NFC}=100-(\% \mathrm{NDF}+\% \mathrm{CP}+\%$ ash $+\%$ ether extract $)$. 
Table 3. Nutrient composition of the control and $0.75 \mathrm{~g} / \mathrm{d}$ acarbose rations for experiment $1^{1}$

\begin{tabular}{lcc}
\hline & \multicolumn{2}{c}{$\%$, DM basis } \\
\cline { 2 - 3 } Component & Control & Acarbose \\
\hline $\mathrm{DM}, \%$ & 54.7 & 54.3 \\
$\mathrm{CP}, \%$ & 17.3 & 17.7 \\
$\mathrm{ADF}, \%$ & 11.2 & 11.5 \\
$\mathrm{NDF}, \%$ & 20.1 & 19.5 \\
$\mathrm{NE}_{\mathrm{L}}, \mathrm{Mcal} / \mathrm{kg}$ & 1.78 & 1.78 \\
$\mathrm{NFC}^{2}$ & 44.7 & 44.6 \\
\hline
\end{tabular}

${ }^{1}$ NRC (2001) values used for percentage ash and ether extract of ration ingredients.

${ }^{2} \mathrm{NFC}=100-(\% \mathrm{NDF}+\% \mathrm{CP}+\%$ ash $+\%$ ether extract $)$.

\section{Experiment 1}

The objective of experiment 1 was to evaluate the effect of acarbose, an amylase and glucosidase inhibitor, on milk yield and composition of lactating dairy cows offered the high-concentrate, low-forage ration in Table 1 (formulation) and Table 3 (nutrient composition). Thirty multiparous lactating dairy cows were selected based on the following criteria: 32 to 52 DIM upon arrival at the facility, 305-d milk yield of $>8,000 \mathrm{~kg}$ during the previous lactation, no metabolic disease in the current lactation, no current mastitis, a BCS of at least 2.5, and trimmed feet. Animals were housed in 2 pens, each equipped with 15 Calan gates (American Calan, Northwood, $\mathrm{NH}$ ) and 2 waterers, were adapted to housing and milking conditions and trained to access feed from Calan gates during the 8 wk before the start of the first period. All animals were offered the 70:30 concentrate:forage ration (Table 1). The study was conducted as a 2-treatment crossover design with two $20-d$ periods. The use of Calan gates enabled different animals in the same pen to be allocated to different treatment sequences. Treatment 1 (control) was the ration with no supplement and treatment 2 (acarbose) was the ration with acarbose incorporated at a rate designed to provide $0.75 \mathrm{~g} / \mathrm{cow}$ per day. Animals were adapted to the rations for the first $13 \mathrm{~d}$ of each period, and the data collected during the last $7 \mathrm{~d}$ were used for treatment comparisons. Animals within each of 2 pens were individually allocated to treatment sequence according to a random treatment allocation plan and averaged 101 DIM at the beginning of the first treatment period.

Feed Intake. Acarbose [UK-88,276, Pfizer Animal Health, Sandwich, UK; prepared from Glucobay tablets (Bayer)] was mixed in the concentrate at a percentage calculated to deliver $0.75 \mathrm{~g} /$ cow per day based on the 5 -d average intake of animals before initiation of treatment. The concentration was modified when average feed intake or ration formulation changed. Concentrate, with or without acarbose, was added to the silage in the TMR mixer once daily in the morning and the TMR was weighed into individual barrels, one per animal, with an estimated $10 \%$ excess. Approximately two-thirds of the feed was offered in the morning and one-third was offered in the afternoon at milking times. Feed remaining the following morning was weighed to calculate daily intake, sampled, and then discarded. Daily individual animal DMI were calculated as described below.

Feed Samples. Feed samples were taken during the data collection period of each treatment period for DM determination. Representative samples of the control and acarbose-containing diets (approximately $400 \mathrm{~g}$ ) were taken from each batch of feed mixed and of feed refused for each cow (approximately $400 \mathrm{~g}$ ) daily. Samples were stored at $4^{\circ} \mathrm{C}$ and at the end of the collection week, 2 composite samples (approximately $1.2 \mathrm{~kg}$ each) of feed offered and refused were prepared. One composite sample was sent to Dairy One Forage Laboratory (Ithaca, NY) for DM analysis (all samples) and nutrient composition (feed offered only); the other sample was retained as a backup. Dry matter was obtained by placing samples at $60^{\circ} \mathrm{C}$ with forced air for $4 \mathrm{~h}$. Crude protein was measured using AOAC 2001.11 method (AOAC, 1995), and ADF and NDF were measured using the Ankom A200 Filter Bag Technique (Ankom Technology, Fairport, NY). Average nutrient composition of the 2 rations for the 2 data collection periods is summarized in Table 3. Daily DMI was calculated for each animal by correcting daily as-fed feed offered using weekly DM of the treatment feed and daily as-fed feed refused using weekly DM for the individual animal.

Milk Production and Samples. Individual cow milk production was recorded at both morning and afternoon milkings. Milk samples were taken during the last $5 \mathrm{~d}$ of each period. Approximately $1.2 \%$ of milk was proportionately sampled by a meter sampler during milking, the sample was swirled, and approximately $30 \mathrm{~mL}$ was poured into a container with a potassium dichromate pellet. Milk samples were sent at 3- to 4-d intervals to Michigan DHIA (Lansing, MI) for measurement of percentage fat, protein, lactose, and solids, using a Combi Bentley 2000 (Bentley Instruments, Chaska, MN).

$B W$ and General Health Observations. Animals were weighed at the beginning and end of each period after the morning milking. Animals were observed at least twice daily and any abnormalities were recorded. Animals were closely monitored for signs of acute acidosis or displaced abomasums and were examined as soon as possible after the observation.

Data Calculations. Individual animal daily as-fed intakes were corrected for DM and individual animal daily milk production (actual and 3.5\% fat-corrected) 
and milk fat, protein, lactose, and solids production were calculated during the third week of each treatment. The following formula was used to calculate $3.5 \%$ FCM production: $\mathrm{FCM}(\mathrm{kg})=0.4324 \times(\mathrm{kg}$ of total daily milk $)+16.216 \times(\mathrm{kg}$ of total daily fat)/1,000 (Gaines, 1927; Brog, 1971). Additionally, individual animal milk production and twice-weekly total milk fat, protein, lactose, and solids production were calculated during the adaptation phase of each period (data not shown).

Statistical Analysis. Animal mean daily feed intake, mean milk production, and milk composition data for the data collection period were analyzed using a linear mixed model for a crossover design. Treatment, period, and treatment by period interaction were fitted as fixed effects. Pen and animal within sequence and pen were fitted as random effects. Because of the use of Calan gates with animals being individually randomized to treatment sequence, the experimental unit for analysis was the individual cow-period. Carry-over effect was not assessed in the analysis. The treatment group least squares means and SEM are reported.

\section{Experiment 2}

The objective of experiment 2 was to determine the effect of acarbose on milk yield and composition of lactating dairy cows offered the ration in Table 1 (formulation) and Table 4 (nutrient composition) and fasted for $3 \mathrm{~h}$ before the morning feeding to induce consumption of a large initial meal. It is noted that the percentages of DM and protein are lower for the acarbose compared with control ration; however, the reason is unknown, because both rations were prepared using the same formulation and ingredients. Feed was removed for measurement of feed refused before the morning milking and fresh feed was weighed into the Calan gate hoppers $3 \mathrm{~h}$ later. The fast was designed to mimic conditions that might occur when feeding is unintentionally delayed, one of the management practices associated with SARA. Thirty multiparous lactating dairy cows were selected based on the following criteria: 32 to 52 DIM at arrival to the facility, 305-d milk yield of $>8,182 \mathrm{~kg}$ in the last lactation, sound (no foot disease, not lame, trimmed hooves), 4 quarters suitable for milking with claws without significant adjustment, SCC $<300,000$ cells/mL in the most recent milk test, no history of mastitis in the current lactation, no acute ketosis, displaced abomasum or metritis in the current lactation, and a BCS $>2.5$. The animals were adapted to housing and milking conditions and were trained to access feed from Calan gates for 4 wk before the start of the first period. The study was conducted as a 2-treatment crossover design with two 21-d treatment periods. The use of Calan gates enabled different animals in
Table 4. Nutrient composition of the control and $0.75 \mathrm{~g} / \mathrm{d}$ acarbose rations for experiment $2^{1}$

\begin{tabular}{lcc}
\hline & \multicolumn{2}{c}{$\%$, DM basis } \\
\cline { 2 - 3 } Component & Control & Acarbose \\
\hline $\mathrm{DM}, \%$ & 50.1 & 47.9 \\
$\mathrm{CP}, \%$ & 19.6 & 18.5 \\
$\mathrm{ADF}, \%$ & 11.9 & 11.5 \\
$\mathrm{NDF}, \%$ & 19.5 & 20.2 \\
$\mathrm{NE}$ & $1.78 \mathrm{Mcal} / \mathrm{kg}$ & 1.77 \\
$\mathrm{NFC}^{2}$ & 42.3 & 43.1 \\
\hline
\end{tabular}

${ }^{1}$ NRC (2001) values used for percentage ash and ether extract of ration ingredients.

${ }^{2} \mathrm{NFC}=100-(\% \mathrm{NDF}+\% \mathrm{CP}+\%$ ash $+\%$ ether extract $)$.

the same pen to be allocated to different treatment sequences. Animals were adapted to the rations for the first $14 \mathrm{~d}$ of each period, and data collected during the last $7 \mathrm{~d}$ were used for treatment comparisons. Treatment 1 (control) was the ration with no supplement and treatment 2 (acarbose) was the ration with acarbose incorporated at a rate designed to provide $0.75 \mathrm{~g} /$ cow per day. Animals were blocked on the basis of milk yield $d-7$ to -2 relative to study start and individually allocated to treatment sequence within each pen according to a random treatment allocation plan and averaged 72 DIM at the beginning of the first treatment period.

Methods for feed preparation, feed intake and analysis measurements, milk yield and composition measurements, daily health observations, and data calculations are as for experiment 1 . The statistical analysis was the same as for experiment 1 with the exception that block; pen; and animal within sequence, pen, and block were included as random effects.

\section{RESULTS}

\section{Preliminary Experiments with a 70:30 Concentrate:Forage SARA Ration}

Preliminary Experiment 1 in Steers. Daily feed intakes, hours with $\mathrm{pH}<5.5$, and average $\mathrm{pH}$ for each animal are summarized in Table 5, and ruminal $\mathrm{pH}$ profiles for d 4 are illustrated in Figure 1. Differences in feed intake within animal ranged from 4.6 (animal 442 ) to $18.0 \mathrm{~kg} / \mathrm{d}$ (animal 448), but were not related to number of hours $\mathrm{pH}<5.5$. During the course of the study, less than $22 \mathrm{~h}$ of $\mathrm{pH}$ data were collected for 6 of the total 25 animal days because of the $\mathrm{pH}$ probe coming disconnected or the harness not staying in place. Ruminal $\mathrm{pH}$ was $<5.5$ for at least $4 \mathrm{~h}$ for 15 of the 19 remaining animal days (79\%), across days for each animal and across animals for each day. Average ruminal $\mathrm{pH}$ was between 5.45 and 5.84 for all animals and between 5.53 and 6.03 for all days. 
Table 5. Feed intake (DMI), number of hours $\mathrm{pH}<5.5$, and average $\mathrm{pH}$ for each individual animal for each day in preliminary experiment 1

\begin{tabular}{|c|c|c|c|c|c|c|c|}
\hline Animal no. & Day 0 & Day 1 & Day 2 & Day 3 & Day 4 & Mean & SEM \\
\hline \multicolumn{8}{|l|}{ DMI, $\mathrm{kg} / \mathrm{d}$} \\
\hline 448 & 12.4 & 2.0 & 6.7 & 9.8 & $\mathrm{NW}^{1}$ & 7.7 & 2.2 \\
\hline 454 & 10.6 & 14.3 & 10.7 & 14.2 & NW & 12.5 & 1.1 \\
\hline 442 & 9.6 & 11.4 & 9.6 & 8.7 & NW & 9.8 & 0.6 \\
\hline 453 & 10.3 & 7.8 & 11.0 & 11.6 & NW & 10.2 & 0.8 \\
\hline Mean & 11.4 & 9.3 & 10.2 & 11.3 & & - & \\
\hline 448 & 10.67 & 0.00 & 0.00 & $\mathrm{NA}^{2}$ & 8.17 & 4.71 & 2.77 \\
\hline 454 & 12.17 & 1.00 & 10.33 & 7.17 & 12.33 & 8.60 & 2.11 \\
\hline 443 & NA & 6.83 & 6.83 & 12.00 & NA & 8.55 & 1.73 \\
\hline 442 & NA & 11.67 & NA & 21.00 & NA & 16.34 & 4.68 \\
\hline 453 & 13.67 & 10.67 & 1.33 & 4.67 & 5.00 & 7.07 & 2.23 \\
\hline Mean & 12.17 & 6.03 & 4.62 & 11.21 & 8.50 & 9.05 & \\
\hline SEM & 0.87 & 2.69 & 2.79 & 3.60 & 2.12 & - & \\
\hline 453 & 5.5 & 5.7 & 6.3 & 5.9 & 5.7 & 5.82 & 0.14 \\
\hline Mean & 5.53 & 5.78 & 6.03 & 5.56 & 5.70 & 5.69 & \\
\hline SEM & 0.03 & 0.06 & 0.19 & 0.13 & 0.06 & - & \\
\hline
\end{tabular}

${ }^{1} \mathrm{NW}=$ not weighed.

${ }^{2} \mathrm{NA}=$ less than $22 \mathrm{~h}$ of $\mathrm{pH}$ data collected.

Preliminary Experiment 2 in Lactating Dairy Cattle. Compared with the 50:50 concentrate:forage ration, the 70:30 concentrate:forage ration decreased feed intake (21.6 vs. $22.9 \mathrm{~kg} / \mathrm{d} ; P<0.05)$, milk fat percentage ( 3.37 vs. $3.64 \% ; P<0.05)$, and milk fat yield (940 vs. $1,020 \mathrm{~g} / \mathrm{d} ; P<0.01$ ), but did not affect milk yield (28.0 vs. $28.1 \mathrm{~kg} / \mathrm{d})$.

\section{Experiment 1}

Results of feeding the ration in experiment 1 with and without acarbose are summarized in Table 6 . Although no treatment by period interactions were significant, they remained in the statistical model, and neither interaction $P$-values nor means are included in Table 6. Feed intake estimates for one animal were excluded from both treatment periods because of an eating behavior that resulted in removal of feed that was not subsequently eaten and could not be measured. Dry matter feed intake was approximately $7 \%$ higher $(P=0.002)$ when animals received acarbose compared with control. Although there was also a period effect, intake being higher during period 1 than period 2, the treatment by period interaction was not significant $(P$ $=0.108$ ). Dry matter feed intakes were 21.2 and 25.0 $\mathrm{kg}$ for control and acarbose treatments, respectively, during period 1 , and were 22.0 and $21.4 \mathrm{~kg}$ for control and acarbose treatments, respectively, during period 2 .

The $3.5 \%$ FCM yield was increased $(P=0.002)$ by 2.0 $\mathrm{kg} / \mathrm{d}$ when acarbose was offered compared with control.
This was because of increased $(P<0.001)$ milk fat percentage and yield (9.5 and $12 \%$, respectively) when acarbose was offered compared with control, because milk yield did not differ between the 2 treatments. Neither percentages nor yields of protein, lactose, and solids were affected by treatment. Body weight gains during the period, which include both the 2-wk adaptation and 1-wk data collection periods, were not influenced by treatment.

\section{Experiment 2}

Results of feeding the ration in Table 1 with and without acarbose in animals experiencing a daily $3-\mathrm{h}$ fast before the morning feeding are summarized in Table 7. Although no treatment by period interactions were significant, they remained in the statistical model, and neither $P$-values nor means are included in Table 7. Dry matter feed intake was $3.2 \%$ higher $(P=0.039)$ during acarbose treatment compared with the control treatment. Although feed intake was higher $(P<0.001)$ during period 1 than period 2, the treatment by period interaction was not significant. Yield of milk fat was also higher during acarbose treatment (1,229 vs. 1,047 $\mathrm{g} / \mathrm{d} ; P<0.001)$. The $3.5 \% \mathrm{FCM}$ yield was increased $(P$ $=0.039)$ by $3.0 \mathrm{~kg} / \mathrm{d}$ because of the $18 \%$ increase $(P<$ $0.001)$ in percentage fat associated with acarbose treatment although milk yield was not affected. Percentages of protein, lactose, and solids were lower $(P=0.026$, 0.014 , and 0.006 , respectively) with acarbose treatment 


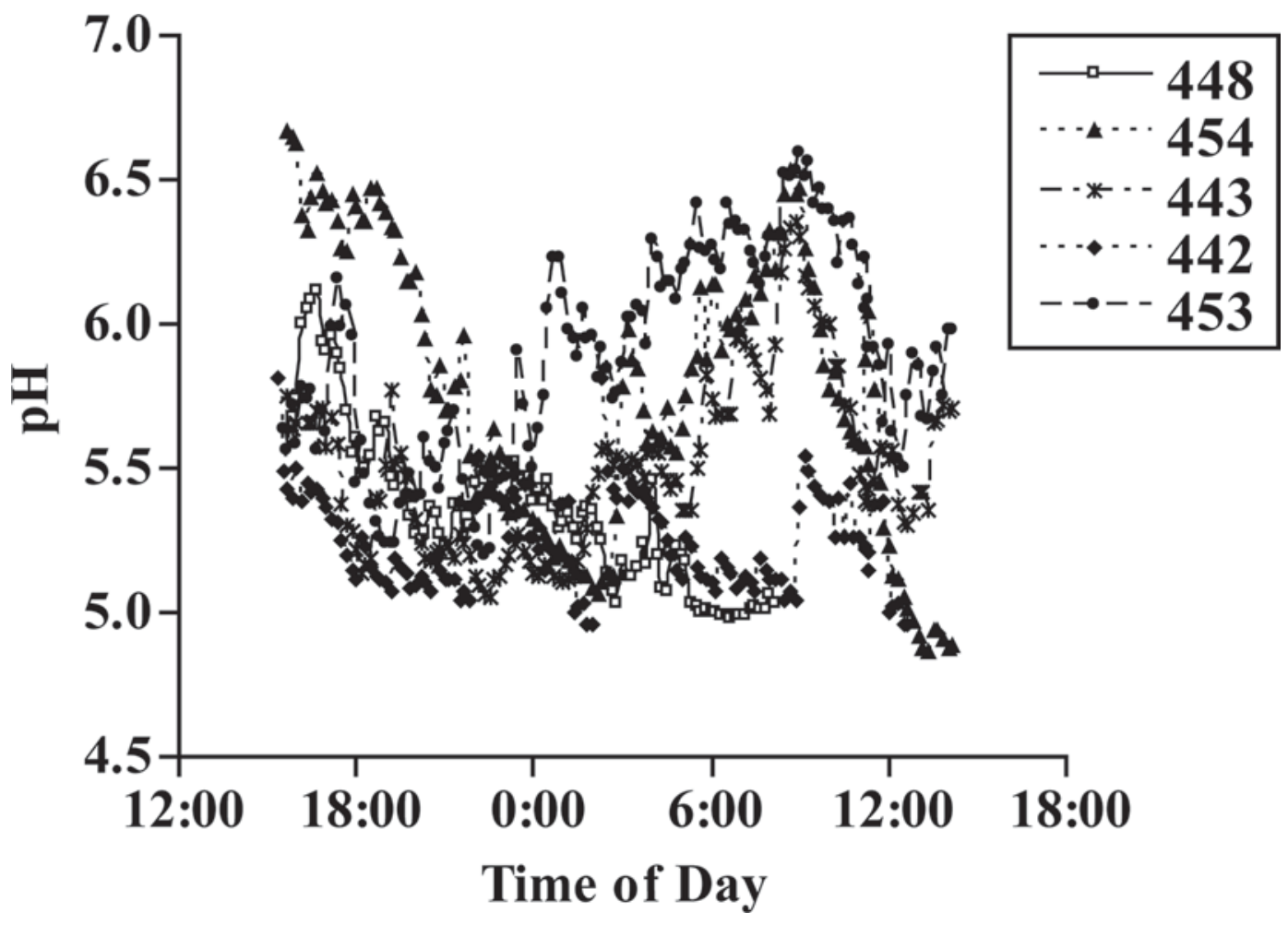

Figure 1. Rumen pH profiles for 5 individual animals on d 4 of preliminary experiment 1.

compared with control. However, the differences were small $(0.06,0.04$, and $0.09 \%$, respectively), and yields of protein, lactose, and solids did not differ between treatments. Significant period effects on yields were predominantly a consequence of the normal decline in milk production as lactation progressed.

Body weight gains during each period, which include both the 2-wk adaptation and 1-wk data collection phases, were not influenced by treatment. During the first period of study, 2 cows that had received acarbose treatment for 9 and $13 \mathrm{~d}$ developed a displaced abomasum and 1 cow (control) experienced a femoral fracture at the end of period 1 . These animals were euthanized.

\section{DISCUSSION}

Continuous monitoring of ruminal $\mathrm{pH}$ as shown by Bach et al. (2007) is the best way of evaluating the ability of a ration to induce SARA. In preliminary experiment 1, SARA (defined by $\mathrm{pH}<5.5$ for at least 4 $\mathrm{h} / \mathrm{d}$ ) was observed on $79 \%$ of the animal days and was

Table 6. Least squares treatment means, SEM, and $P$-values for lactating dairy cows receiving rations with 0 (control) or $0.75 \mathrm{~g}$ of acarbose/d during early lactation in experiment 1

\begin{tabular}{|c|c|c|c|c|c|}
\hline \multirow[b]{2}{*}{ Variable } & \multicolumn{2}{|c|}{ Treatment } & \multirow[b]{2}{*}{ SEM } & \multicolumn{2}{|c|}{$P$-value } \\
\hline & Control $(\mathrm{n}=30)$ & Acarbose $(\mathrm{n}=30)$ & & Treatment & Period \\
\hline $3.5 \%$ FCM yield, $\mathrm{kg} / \mathrm{d}$ & 31.7 & 33.7 & 1.6 & 0.002 & $<0.001$ \\
\hline Milk yield, $\mathrm{kg} / \mathrm{d}$ & 34.5 & 34.5 & 1.4 & 0.955 & 0.052 \\
\hline Fat yield, $\mathrm{g} / \mathrm{d}$ & 1,035 & 1,158 & 75 & $<0.001$ & $<0.001$ \\
\hline Protein yield, g/d & 1,059 & 1,047 & 40 & 0.519 & 0.041 \\
\hline Fat, $\%$ & 3.04 & 3.33 & 0.17 & $<0.001$ & $<0.001$ \\
\hline Protein \% & 3.09 & 3.05 & 0.05 & 0.057 & 0.292 \\
\hline Lactose, \% & 4.63 & 4.63 & 0.09 & 0.833 & 0.031 \\
\hline Solids, \% & 8.62 & 8.58 & 0.12 & 0.089 & 0.470 \\
\hline Weight gain, $\mathrm{kg} /$ period & 13.5 & 10.9 & 6.2 & 0.564 & 0.384 \\
\hline
\end{tabular}


Table 7. Least squares treatment means, SEM, and $P$-values for lactating dairy cows receiving rations with 0 (control) or $0.75 \mathrm{~g}$ of acarbose / cow/d after a daily 3 -h feed withhold in experiment 2

\begin{tabular}{|c|c|c|c|c|c|}
\hline \multirow[b]{2}{*}{ Variable } & \multicolumn{2}{|c|}{ Treatment } & \multirow[b]{2}{*}{$\mathrm{SEM}^{1}$} & \multicolumn{2}{|c|}{$P$-value } \\
\hline & Control $(\mathrm{n}=28)$ & Acarbose $(\mathrm{n}=27)$ & & Treatment & Period \\
\hline $3.5 \%$ FCM yield, $\mathrm{kg} / \mathrm{d}$ & 33.9 & 36.9 & 1.3 & $<0.001$ & $<0.001$ \\
\hline Milk yield, kg/d & 39.2 & 39.3 & 1.2 & 0.734 & $<0.001$ \\
\hline Fat yield, g/d & 1,046 & 1,229 & 58 & $<0.001$ & $<0.001$ \\
\hline Protein yield, g/d & 1,144 & 1,129 & 29 & 0.255 & $<0.001$ \\
\hline Fat, $\%$ & 2.66 & 3.14 & 0.14 & $<0.001$ & $<0.001$ \\
\hline Protein \% & 2.94 & 2.89 & 0.04 & 0.026 & 0.167 \\
\hline Lactose, $\%$ & 4.72 & 4.68 & 0.03 & 0.014 & 0.344 \\
\hline Solids, \% & 8.57 & 8.48 & 0.05 & 0.006 & 0.053 \\
\hline Weight gain, $\mathrm{kg} /$ period & 7.6 & 8.6 & 4.4 & 0.861 & 0.273 \\
\hline
\end{tabular}

${ }^{1}$ Largest SEM for treatment means.

observed for the averages of each animal and each day of the experiment in Holstein steers. Using large Holstein steers was considered the best alternative to measuring ruminal $\mathrm{pH}$ in early-lactation dairy cows. Although the BW of steers and lactating cows were similar, it is recognized that the steers eat less per kilogram of BW than lactating cows. It may be argued that the same ration would induce more severe SARA in lactating cows with much higher intakes per kilogram of BW.

Although by itself not considered an indicator of SARA, low percentage milk fat is commonly associated with the condition, and in preliminary experiment 2 , milk fat percentage and yield were lower in cows offered the ration in Table 1 compared with a 50:50 concentrate:forage ration. The effects of this ration on rumen $\mathrm{pH}$ profile in steers and intake and fat percentage and yield in lactating cows indicate that the ration used in the 2 main experiments reported may increase the risk of SARA.

The milk fat percentage for control animals observed in these 2 experiments is consistent with levels expected with a 75:25 concentrate:forage ration (Khorasani and Kennelly, 2001; Krause et al., 2003). In several large surveys in which both ruminal $\mathrm{pH}$ and percentage milk fat were both measured, low $\mathrm{pH}$ was associated with lower percentages of milk fat either for individual animals or herds from which they come (Bramley et al., 2008; Enemark, 2008; O'Grady et al., 2008). Acarbose treatment increased the percentage fat by 0.29 and 0.49 units in experiments 1 and 2, respectively. The increase in milk fat associated with acarbose treatment may be related to the alteration of acetate:propionate ratio. When rations with differing concentrate:forage ratios are compared, rations with higher concentrate:forage ratios were associated with lower acetate:propionate ratio even if total ruminal VFA concentrations were increased or unaffected. This effect has been observed in both experimental studies (Khorasani and Kennelly, 2001; Krause et al., 2003) and large surveys (Bramley et al., 2008; O'Grady et al., 2008). Acarbose decreases total VFA concentration and increases acetate:propionate ratio, which may be partially responsible for supporting increased milk fat (Speight et al., 2007).

One sign of SARA is decreased intake as demonstrated in preliminary experiment 2 in lactating dairy cattle when the ration in Table 1 was compared with a 50:50 concentrate:forage ration. However, this is not a consistent finding and feed intake may actually be higher when a high carbohydrate:forage ration is fed in the short-term (Khorasani and Kennelly, 2001; Maekawa et al., 2002). Feed intake in the present experiments was increased with acarbose treatment and may have supported the increased energy output in the milk fat because neither milk yield nor BW gain was affected.

Rations with high concentrate:forage ratio and highly fermentable carbohydrates are used to support high milk yield but also increase risk of SARA (O'Grady et al., 2008). However, these rations and consequent effects on $\mathrm{pH}$ do not consistently affect milk yield in experimental conditions (Khorasani and Kennelly, 2001; Maekawa et al., 2002; Krause et al., 2003) or surveys of multiple farms (Bramley et al., 2008). Further, in the preliminary experiment, no difference in milk yield was observed when cows were offered the ration in Table 1 compared with a 50:50 concentrate:forage ration. Thus, the lack of effect of acarbose on milk yield may not be surprising.

In experiment 2, a 3-h fast was introduced to increase the size of the first meal after the morning milking and potentially exacerbate the decrease in $\mathrm{pH}$ that normally follows feeding. The cows appeared to adapt within a few days to the delayed feeding pattern, resting until 
they knew they had access to feed. Compared with experiment 1 (ad libitum feeding), responses to acarbose in experiment 2 (feeding after a 3 -h fast) were similar with the exception that $3.5 \%$ FCM yield was increased more $(3.0$ vs. $2.0 \mathrm{~kg} / \mathrm{d})$ and there were 2 displaced abomasums in acarbose-treated cattle in experiment 2. Subacute ruminal acidosis has been associated with a higher incidence of displaced abomasum, and a low forage ration is considered the most important factor in their occurrence (Shaver, 2005; Enemark, 2008).

Thus, acarbose, an amylase and glucosidase inhibitor that prevents the decrease in $\mathrm{pH}$ associated with a high concentrate:forage ration (Keane et al., 2008), restored milk fat, increased 3.5\% FCM, and increased feed intake in animals offered a high carbohydrate:forage ration that induced SARA in Holstein steers.

\section{CONCLUSIONS}

Lactating cows were offered a ration that induced SARA in Holstein steers and resulted in low percentage milk fat in dairy cows. Addition of acarbose, an amylase and glucosidase inhibitor, restored the decreased percentage milk fat associated with SARA and increased $3.5 \%$ FCM and feed intake.

\section{REFERENCES}

AOAC. 1995. Official Methods of Analysis, 16th ed. AOAC Int., Arlington, VA.

Bach, A., and S. Andrieu. 2007. Effects of Yea-Sacc1026 supplementation on rumen $\mathrm{pH}$ of loose-housed dairy cattle. J. Dairy Sci. 90(Suppl. 1):108-109. (Abstr.)

Bach, A., C. Iglesias, and M. Devant. 2007. Daily rumen pH pattern of loose-housed dairy cattle as affected by feeding pattern and live yeast supplementation. Anim. Feed Sci. Technol. 136:147-153.

Bramley, E., I. J. Lean, W. J. Fulkerson, M. A. Stevenson, A. R Rabiee, and N. D. Costas. 2008. The definition of acidosis in dairy herds predominantly fed on pasture and concentrates. J. Dairy Sci. 91:308-321.

Brog, R. A. 1971. Is fat-corrected milk sufficient? J. Dairy Sci. 54:1137-1141.

Enemark, J. M. D. 2008. The monitoring, prevention and treatment of sub-acute ruminal acidosis (SARA): A review. Vet. J. 176:3243.

Gaines, W. L. 1927. The energy basis of measuring milk yield in dairy cows. Univ. Ill. Agric. Exp. Sta. Bull. 308:413-438.

Garrett, E. F., M. N. Pireira, K. V. Nordland, L. E. Armentano, W. J. Goodger, and G. R. Oetzel. 1999. Diagnostic methods for the detection of subacute ruminal acidosis in dairy cows. J. Dairy Sci. 82:1170-1178

Higginbotham, G. E., G. A. Clooar, M. S. Aseltine, and D. L. Bath 1994. Effect of yeast culture and Aspergillus oryzae extract on milk yield in a commercial dairy herd. J. Dairy Sci. 77:343-348.

Hu, W. P., and M. R. Murphy. 2005. Statistical evaluation of early- and mid-lactation dairy cow responses to dietary sodium bicarbonate addition. Anim. Feed Sci. Technol. 119:43-54.

Keane, J., L. McLaughlin, P. Thompson, G. Greenwood, and I. Bruce. 2008. Control of ruminal $\mathrm{pH}$ in an acute acidosis model. Page
27 in Proc. XXV Jubilee World Buiatrics Congress, Budapest, Hungary.

Khorasani, G. R., and J. J. Kennelly. 2001. Influence of carbohydrate source and buffer on rumen fermentation characteristics, milk yield, and milk composition in late-lactation Holstein cows. J. Dairy Sci. 84:1707-1716.

Krause, K. M., D. K. Combs, and K. A. Beauchemin. 2003. Effects of increasing levels of refined cornstarch in the diet of lactating dairy cows on performance and ruminal pH. J. Dairy Sci. 86:13411353

Krause, K. M., and G. R. Oetzel. 2005. Inducing subacute ruminal acidosis in lactating dairy cows. J. Dairy Sci. 88:3633-3639.

Krause, K. M., and G. R. Oetzel. 2006. Understanding and preventing subacute ruminal acidosis in dairy herds: A review. Anim. Feed Sci. Technol. 126:215-236.

Kuenen, J. E., J. C. Plaizier, I. Kyriazakis, T. F. Duffield, T. M. Widowski, M. I. Lindinger, and B. W. McBride. 2002. Effects of a subacute ruminal acidosis model on the diet selection of dairy cows. J. Dairy Sci. 85:3304-3313.

Maekawa, M., K. A. Beauchemin, and D. A. Christensen. 2002. Effect of concentrate level and feeding management on chewing activities, saliva production, and ruminal $\mathrm{pH}$ of lactating dairy cows. J. Dairy Sci. 85:1165-1175.

McLaughlin, C. L., A. Thompson, K. Greenwood, J. Sherington, and C. Bruce. 2009. Effect of acarbose on acute acidosis. J. Dairy Sci. 92:2758-2766

Mutsvangwa, T., J. P. Walton, J. C. Plaizier, T. F. Duffield, R. Bagg, P. Dick, G. Vessie, and B. W. McBride. 2002. Effects of a monensin controlled-release capsule or premix on attenuation of subacute acidosis in dairy cows. J. Dairy Sci. 85:3454-3461.

NRC. 2001. Nutrient Requirements of Dairy Cattle. 7th rev. ed. Natl Acad. Sci., Washington, DC.

O'Grady, L., M. L. Doherty, and F. J. Mulligan. 2008. Subacute ruminal acidosis (SARA) in grazing Irish dairy cows. Vet. J. 176:44-49.

Oetzel, G. R., K. M. Emery, W. P. Kautz, and J. E. Nocek. 2007. Direct-fed microbial supplementation and health and performance of pre- and postpartum dairy cattle: A field trial. J. Dairy Sci. 90:2058-2068

Owens, F. N., D. S. Secrist, W. J. Hill, and D. R. Gill. 1998. Monensin and abomasal protein passage of steers. J. Anim. Sci. 76:275286.

Paton, L., K. Beauchemin, D. Viera, and M. von Keyserlingk. 2006. Use of sodium bicarbonate, offered free choice or blended into the ration, to reduce the risk of ruminal acidosis in cattle. Can. J. Anim. Sci. 86:429-437.

Plaizier, J. C., D. O. Krause, G. N. Gozho, and B. W. McBride. 2008 Subacute ruminal acidosis in dairy cows: The physiological causes, incidence and consequences. Vet. J. 176:21-31.

Swartz, D. L., L. D. Muller, G. W. Rogers, and G. A. Varga. 1994 Effect of yeast cultures on performance of lactating dairy cows: A field study. J. Dairy Sci. 77:3073-3080.

Shaver, R. 2005. Feeding to minimize acidosis and laminitis in dairy cows. Pages 157-166 in Proceedings of the VIIth Western Dairy Management Conference, March, Reno, NV.

Speight, S. M., and D. L. Harmon. 2005. Application of carbohydrate inhibitors to moderate rumen fermentation: In vitro examination. J. Dairy Sci. 83(Suppl. 1):307. (Abstr.)

Speight, S. M., D. L. Harmon, and J. M. Tricarico. 2007. Application of carbohydrate inhibitors to moderate rumen fermentation continuous culture evaluation. J. Dairy Sci. 90(Suppl. 1):340. (Abstr.)

Thrune, M., A. Bach, M. Ruiz-Moreno, M. D. Stern, and J. G. Linn. 2009. Effects of Saccharomyces cerevisiae on ruminal $\mathrm{pH}$ and microbial fermentation in lactating dairy cows. Livest. Sci. doi:10.1016/j.livsci.2009.2.007 